\title{
Daniel Zagury cleared of misconduct charges
}

\section{Washington}

Allegations that Daniel Zagury violated medical codes of ethics in experimental trials of an AIDS vaccine are unfounded, according to French medical officials who investigated the charges that were first raised by a reporter from the Chicago Tribune. Three of Zagury's patients, each in the advanced stages of AIDS, died from a reaction to the experimental vaccine.

The French Conseil Regional de l'Ordre National des Médécins not only concluded that Zagury and his colleagues, acted ethically in their experiments at the Saint Antoine Hospital in Paris, but also pointed out that all medical trials necessarily include some risk and that by participating in the vaccine trials the patients did not face a risk "out of proportion to [their] state of health and diagnosis". Each had T4 lymphocyte counts of less than $50 / \mathrm{mm}$, which usually puts AIDS patients close to death.

Zagury's judges went so far as to say that with AIDS, "research is a duty" and that "it is legitimate for [Zagury] to follow this work on active immunology in order to determine whether it offers a useful treatment for this disease."

Since 1987 Zagury has been working on what he calls "active immunotherapy" for AIDS patients - a vaccine that uses the patients own cells, infected in vitro with inactivated recombinant vaccinia virus engineered to express human immune deficiency virus(HIV) antigens. In an effort to boost AIDS immunity in the three patients who were subsequently found to have died of vaccinia necrosis, Zagury administered the vaccine by three routes - intravenous, intramuscular and subcutaneous injection.

Zagury says that he did not immediately suspect vaccinia necrosis as the cause of death in his first two patients, mainly because he (and others) had considerable experience with inactivated vaccinia and, even though it can be hazardous to immunocompromised individuals, "at first we did not think that was it". Once another researcher, using monoclonal antibodies to search for vaccinia antigen, found it in the keratinocytes of the deceased, Zagury says he was convinced that their deaths were due to vaccinia. "At that point, we stopped the subcutaneous injections altogether - in all patients in the trial," he says.

In its report exonerating Zagury of ethical misconduct, the council notes that he sought approval from the hospital ethics committee in 1987, before such approval was required by law, and again in 1990 , and concludes from this that Zagury and his colleagues were acting openly and in compliance with ethical cannons. Furthermore, the patients gave written

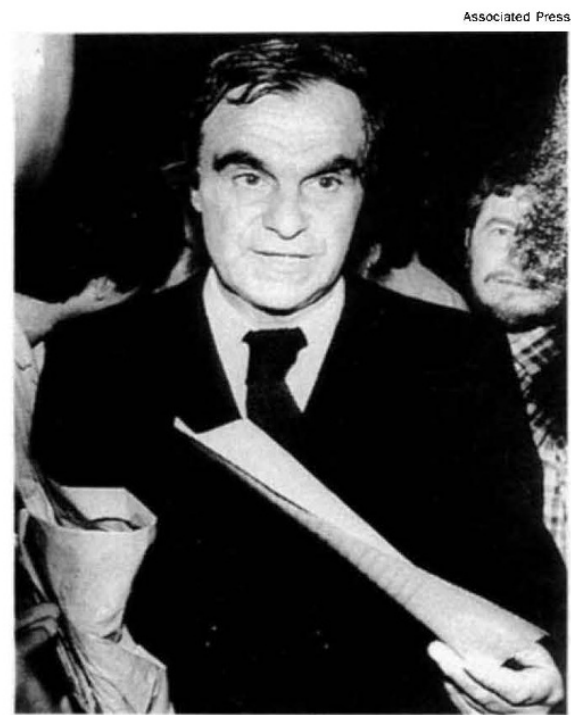

Zagury vindicated.

informed consent for the studies and were covered by an insurance policy that covers experimental studies.

It is no surprise that Zagury is relieved by the exoneration which, he says, is important not only to him but also to "my family's honor and to medicine".

Barbara J. Culliton

\section{Call for UK gene therapy}

\section{London}

BRITAIN needs a new expert panel to assess proposals for human gene therapy experiments, according to an independent committee chaired by the lawyer Sir Cecil Clothier, which was asked by the UK Department of Health to consider the ethical questions associated with gene therapy. As expected, the report concludes that somatic gene therapy poses no special ethical problems, but recommends a moratorium on the manipulation of germ line cells (see Nature 355, 190; 16 January 1991). Somatic cell gene therapy should only be used to alleviate genetic disease, not to change normal human characteristics, the report recommends.

In addition to scrutiny by local research ethics committees at hospitals where gene therapy is planned, the Clothier committee says that all proposals should be vetted by a national body (A similar procedure is followed in the United States for all government-funded research.) This should contain scientific and medical experts, able to advise on the conduct of the research, and lay representatives. The Department of Health intends to consult with interested bodies for the next four months, before acting on the report's recommendations. Until a new national committee is set up, the Clothier committee will stay in place, to review any gene therapy research proposals that may come forward. P.A.

\section{Will EC policy boost European health studies?}

\section{London}

THE European Commission may in future become an important player in medical research funding, under the new European Communities'(EC) treaties agreed at the Maastricht summit of European leaders in December, which commit the EC states to greater economic and political unity. Buried in the reams of paper now being studied by EC lawyers is a chapter on public health, which says that the Commission may support research into the most important health problems in Europe.

This is the first time that the Commission has been given an explicit mandate to promote medical research aimed at problems of public health. If interpreted liberally, the wording could lead to a significant increase in the Commission's spending on medical research. The current five-year EC medical research programme, just getting under way, amounts to only 131 million ECU (approximately $\$ 92$ million).

Commission officials say it is too early to predict the precise effect that the new profile given to public health will have on EC research spending. The Maastricht agreement has yet to be ratified by the EC member states (something that could take a year or more), after which a high-level committee set up by social affairs commissioner Vasso Papandreou will decide which diseases to target with new research programmes.

The text of the agreement reached at Maastricht mentions drug dependency as one example of priority, but it is expected that the prevention of cancer and cardiovascular disease - Europe's major killers - will be priority areas for research as well.

Peter Aldous 